\title{
Water Pollution by Industrial Effluent and Phytoplankton Diversity of Shitalakhya River, Bangladesh
}

\author{
S. M. D. Islam*, M. E. Huda \\ Department of Environmental Sciences, Jahangirnagar University, Dhaka-1342, Bangladesh \\ Received 23 September 2015, accepted in final revised form 19 January 2016
}

\begin{abstract}
The present study investigated the water quality of Shitalakhya River, phytoplankton abundance, diversity and the effect of pollutants on phytoplankton as well as the primary productivity. The water of the collected samples was mostly alkaline (7.01-8.2) and showed a wide range of variation in EC $(1171-2700 \mu \mathrm{S} / \mathrm{cm})$, TDS $(576-1345 \mathrm{mg} / \mathrm{L})$, DO $(0.92-2.7$ $\mathrm{mg} / \mathrm{L})$, free- $\mathrm{CO}_{2}(15-31 \mathrm{mg} / \mathrm{L}), \mathrm{BOD}(12.03-28.38 \mathrm{mg} / \mathrm{L})$ and COD $(101.2-109.2 \mathrm{mg} / \mathrm{L}) . \quad \mathrm{A}$ total of 62 species were identified of which 9 belonged to Chlorophyceae, 11 Cyanophyceae, 14 Euglenophyceae and 28 Bacillariophyceae. Among all the members, Bacillariophyceae were found to be dominant and lowest of Chlorophyceae indicates that this group is more sensitive to the pollutants discharged by the industry.
\end{abstract}

Keywords: Water quality; Industrial effluent; Phytoplankton; Biodiversity; Aquatic ecosystem.

(C) 2016 JSR Publications. ISSN: 2070-0237 (Print); 2070-0245 (Online). All rights reserved.

doi: http://dx.doi.org/10.3329/jsr.v8i2.26402 J. Sci. Res. 8 (2), 191-198 (2016)

\section{Introduction}

Water is the most valuable and vital resource for sustenance of life. Freshwater makes up only less than 3 percent of earth's water and is the source of virtually all drinking waters [1]. Some 55 percent of that water comes from reservoirs, rivers, streams and lakes; and these sources are vulnerable to pollution. Rapid urbanization and industrialization of Bangladesh have negative implications for water quality, where the industrial effluents directly discharge into the rivers without any consideration of the environment [2]. Phytoplankton constitutes the foundation of the food web in aquatic ecosystems and represents one of the most direct and profound responses to pollution entering water bodies $[3,4]$. These microscopic plants are conveniently qualified as suitable indicators $[5,6]$, because they are simple, capable of quantifying changes in water quality, applicable over large geographic areas and can also furnish data on background conditions and natural variability $[7,8]$. In Bangladesh, some studies have been conducted on running and stagnant freshwater habitats using phytoplankton species as indicators by several authors

\footnotetext{
Corresponding author: smdidarulislamju@gmail.com
} 
[9-11]. In the country, most of the industries like textiles, pharmaceuticals, tanneries, paper mills and oil refineries are situated on the bank of rivers and discharge their effluents directly into it. Besides, huge quantities of solid waste from river-side settlements, varieties of chemical fertilizers and residues of pesticides, petroleum products from ships, launches, cargoes, boats, untreated sewage etc. regularly get dumped into these rivers [12]. These pollutants inhibit the growth of aquatic flora and fauna [13]. Thus aquatic diversity is now in threatened condition. The flow of energy in any ecosystem starts with the fixation of sunlight by plants and other autotrophic organisms. In this way the phytoplankton accumulate which is called primary production and the rate at which this energy accumulates is called primary productivity [14]. The primary productivity of the aquatic ecosystem is now adversely affected by various anthropogenic activities and dumping of industrial effluents into river.

In Bangladesh, a very few reports do exist except [11,15], on the effects of industrial effluents on phytoplankton habitat. The present study was therefore undertaken to investigate the water quality of Shitalakhya River, its effects on phytoplankton habitat and assess the diversity and abundance of phytoplankton species.

\section{Material and Methods}

Water samples were collected from 10 locations of the Shitalakhya River (Fig. 1), at Naryanganj district receiving effluents from different industries i.e., textiles, pharmaceuticals, paper mill etc. in January-May, 2015. Geographical locations of each

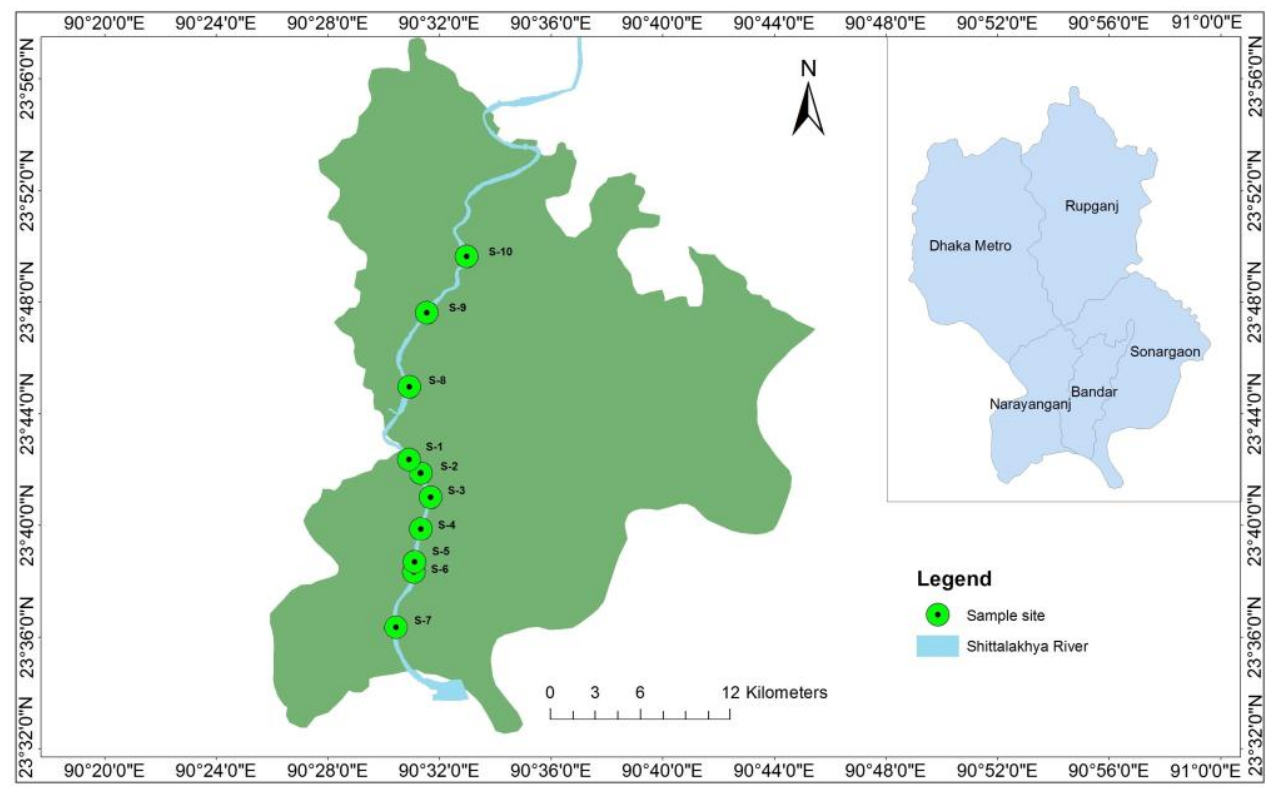

Fig. 1. Map showing the sampling points of Shitalakhya River. 
sampling point were determined by GARMIN handheld global positioning system (GPS). Arc.GIS (Version 10.1) has been used for mapping and showing the sample locations. During sampling, sample bottles were rinsed with river water to be sampled three times. Water samples were collected from the depth of about $15-25 \mathrm{~cm}$ from surface and tried to avoid bubble formation and addition of suspended particles as possible. All the samples were properly labelled and carried out using disposable hand gloves with proper care and stored in ice box. The pH, Dissolved Oxygen (DO), Total Dissolved Solids (TDS) of river water were measured on spot by using calibrated digital multi-meter $(\mathrm{HACH}, 51910)$ and temperature using mercury centigrade thermometer. Electric conductance (EC) was measured at $25{ }^{\circ} \mathrm{C}$ in $\mu \mathrm{S} / \mathrm{cm}$, using an electric conductivity meter (HANNA, HI 8033). Biological Oxygen Demand (BOD) was done by 5 -days incubation, $20^{\circ} \mathrm{C}$ method [16] and COD measured by closed reflux colorimetric method using Colorimeter $\mathrm{HACH}$, $\mathrm{DR} / 890$ ). Free- $\mathrm{CO}_{2}$ was also measured by following APHA standard method [16]. For biological analyses collection, preservation and qualitative assessment of phytoplankton were done by following Khondker et al. (1988) [17] and Johansen (1940) [18] using an electronic microscope and the classification proposed by Bold and Wynne (1985) [19] was followed.

\section{Results and Discussion}

\subsection{Water quality}

Physicochemical parameters of the 10 sampling points are presented in Table 1 . River water comprises temperature from $27-31^{\circ} \mathrm{C}$ with an average $28.6^{\circ} \mathrm{C}$, and the range of $\mathrm{pH}$ from 7.01-8.2 with an average 7.51 (Table 1). Generally aquatic organisms are affected by $\mathrm{pH}$, because most of their metabolic activities are dependent on it. It is an important indicator of water quality and the extent of pollution in aquatic ecosystem [20]. Optimal range of $\mathrm{pH}$ for sustainable aquatic life is 6.5-8.0 [21] and result showed that, $\mathrm{pH}$ values were within the permissible limit except the sample $\mathrm{S}-7$. Fluctuations in $\mathrm{pH}$ values within different sampling points attributes the factors like removal of $\mathrm{CO}_{2}$ by photosynthesis through bicarbonate degradation, dilution of waste with fresh water, reduction of temperature, and decomposition of organic matter [22].

Electric conductivity (EC) showed a wide variation from $1171 \mu \mathrm{S} / \mathrm{cm}$ to $2700 \mu \mathrm{S} / \mathrm{cm}$ with an average $1671.10 \mu \mathrm{S} / \mathrm{cm}$. Although it is not a human or aquatic health concern; but it can serve as an indicator of other water quality parameters. The acceptable range of EC for recreational water is $500 \mu \mathrm{S} / \mathrm{cm}$, irrigation is $750 \mu \mathrm{S} / \mathrm{cm}$ and aquaculture is $800-1000$ $\mu \mathrm{S} / \mathrm{cm}$ [23]. From the study it showed that, measured EC of the Shitalakhya River was below the acceptable range. In water, total dissolved solids (TDS) are composed mainly of carbonates, bicarbonates, chlorides, phosphates and nitrates of calcium, magnesium, sodium, potassium and manganese, organic matter, salt and other particles [24]. The high TDS value of the water is the result of different sewage, domestic waste, industrial and agricultural effluents. In the collected samples, TDS varied from 576-1375 mg/L with an 
average $857.5 \mathrm{mg} / \mathrm{L}$ (Table 1). The acceptable standard of TDS for drinking water is 1000 $\mathrm{mg} / \mathrm{L}$ industrial water is $1500 \mathrm{mg} / \mathrm{L}$ and irrigation is $2000 \mathrm{mg} / \mathrm{L} \mathrm{[23].} \mathrm{The} \mathrm{values} \mathrm{of} \mathrm{all}$ measured samples except, S-1, S-2, S-6 and S-7 were fall within permissible limit of drinking, industrial and agricultural uses.

Dissolved oxygen (DO) is most vital parameters in water quality assessment and reflects the physical and biological processes prevailing in the water [25]. Where the rates of respiration and organic decomposition are high, the DO values usually remain lower, than where the rate of photosynthesis is high [26]. When the water is polluted with large amount of organic matter, a lot of dissolved oxygen would rapidly consumed in the biological aerobic decay which would affect the water quality and aquatic lives [27,28]. The DO concentration of Shitalakhya River varied from $0.92-2.7 \mathrm{mg} / \mathrm{L}$ with an average $1.57 \mathrm{mg} / \mathrm{L}$. In case of dissolved oxygen, standard for sustaining aquatic life is $5.0 \mathrm{mg} / \mathrm{L}$, whereas drinking water purpose is $6.0 \mathrm{mg} / \mathrm{L} \mathrm{[29].} \mathrm{The} \mathrm{acceptable} \mathrm{range} \mathrm{of} \mathrm{DO} \mathrm{for}$ domestic water supplies is 4.0-6.0 mg/L by United State Public Health (USPH) standard [30]. The standard range of DO for fish culture is $5.0 \mathrm{mg} / \mathrm{l}$ to saturation [31] and more than $5.0 \mathrm{mg} / \mathrm{L}$ [32]. According to the environmental quality standard (EQS), DO level should be $6.0 \mathrm{mg} / \mathrm{l}$ for drinking, 4.0-5.0 mg/L for recreation, 4.0-6.0 mg/L for fish and livestock and $5.0 \mathrm{mg} / \mathrm{L}$ for industrial application [33]. On the basis of the study, the measured values of DO of Shitalakhya River water were not within the acceptable range and not suitable for aquatic lives.

Table 1. Physicochemical parameters of the water samples of Shitalakhya River.

\begin{tabular}{|c|c|c|c|c|c|c|c|c|c|c|c|}
\hline \multirow[t]{2}{*}{ Parameters } & \multicolumn{11}{|c|}{ Sampling points } \\
\hline & S-1 & S-2 & S-3 & S-4 & S-5 & S-6 & S-7 & S-8 & S-9 & S-10 & Avg. \\
\hline $\begin{array}{l}\text { Water temp. in } \\
{ }^{\circ} \mathrm{C}\end{array}$ & 27 & 28 & 27 & 31 & 28 & 28 & 29 & 28 & 29 & 31 & 28.6 \\
\hline $\mathrm{oH}$ & 7.43 & 7.47 & 7.63 & 7.38 & 7.41 & 8.0 & 8.2 & 7.25 & 7.37 & 7.01 & 7.51 \\
\hline $\mathrm{EC}(\mu \mathrm{S} / \mathrm{cm})$ & 2130 & 2700 & 1224 & 1295 & 1601 & 2170 & 1807 & 1312 & 1301 & 1171 & 1671.10 \\
\hline TDS & 1067 & 1375 & 606 & 639 & 797 & 1147 & 1097 & 647 & 642 & 576 & 857.5 \\
\hline DO ( & 0.92 & 1.22 & 2.7 & 1.35 & 1.38 & 2.2 & 1.2 & 1.03 & 1.2 & 2.5 & 1.57 \\
\hline $\begin{array}{l}\text { Free } \mathrm{CO}_{2} \\
(\mathrm{mg} / \mathrm{L})\end{array}$ & 19 & 17 & 25 & 13 & 31 & 15 & 16 & 19 & 19 & 17 & 19.10 \\
\hline BOD $(\mathrm{mg} /$ & .12 & 5.24 & 62 & 7.98 & 16.18 & 15.54 & 28.38 & 12.03 & 14.98 & 16.54 & 17.16 \\
\hline $\mathrm{COD}(\mathrm{mg} / \mathrm{L})$ & 05.3 & 105.6 & 107.2 & 104.1 & 104.9 & 108.9 & 109.2 & 102.6 & 102.2 & 101.2 & 105.12 \\
\hline
\end{tabular}

Free $\mathrm{CO}_{2}$ is essential components for photosynthetic plants or organisms and in the study area it was reported from 13-25 mg/L (average $19.10 \mathrm{mg} / \mathrm{L}$ ), are not suitable for living organisms. Biochemical oxygen demand is a measure of the oxygen in the water that is required by the aerobic organisms. High BOD levels indicate lower in DO, because the oxygen that is available in the water is being consumed by the bacteria leading to the inability of fish and other aquatic organisms to survive in the river [34]. The values of BOD of the collected samples were $12.03-22.12 \mathrm{mg} / \mathrm{L}$ with average $17.16 \mathrm{mg} / \mathrm{L}$. The permissible limit for BOD for drinking water is $0.2 \mathrm{mg} / \mathrm{L}$, for recreation $3.0 \mathrm{mg} / \mathrm{L}$, for fish culture $6.0 \mathrm{mg} / \mathrm{L}$ and $10.0 \mathrm{mg} / \mathrm{L}$ for irrigation [21]. COD is commonly used to measure 
the amount of organic compounds presents in water, which makes COD as an indicator of organic pollution of surface water [20]. COD pointing to a deterioration of the water quality caused by the discharge of industrial effluent [35]. The value of the COD varied from 101.2-109.2 $\mathrm{mg} / \mathrm{L}$ and average $105.12 \mathrm{mg} / \mathrm{L}$. All the observed values indicate that, water quality is deteriorated by nearby industrial effluent discharge. Islam and Azam [36] also found very similar observation in case of water quality deterioration of Shitalakhya River.

\subsection{Phytoplankton diversity and abundance}

Table 2. List of the observed phytoplankton in water samples of Shitalakhya River.

\begin{tabular}{|c|c|c|c|c|c|c|c|c|c|c|c|c|c|}
\hline \multirow[t]{2}{*}{ Species Class } & \multirow[t]{2}{*}{ Species Family } & \multirow{2}{*}{$\begin{array}{l}\text { No. of } \\
\text { identified } \\
\text { species }\end{array}$} & \multirow{2}{*}{$\begin{array}{l}\begin{array}{l}\text { Abund- } \\
\text { ance }\end{array} \\
\end{array}$} & \multicolumn{10}{|c|}{ Sampling point wise identified species } \\
\hline & & & & $\overline{\text { S1 }}$ & $\mathrm{S} 2$ & S3 & $\mathrm{S} 4$ & S5 & S6 & S7 & S8 & S9 & S10 \\
\hline \multirow{6}{*}{ Cyanophyceae } & Chroococcaceae & 4 & ++ & $\sqrt{ }$ & & $\sqrt{ }$ & & & & & $\sqrt{ }$ & $\sqrt{ }$ & $\sqrt{ }$ \\
\hline & Oscillatoriaceae & 4 & +++ & $\sqrt{ }$ & $\sqrt{ }$ & & $\sqrt{ }$ & $\sqrt{ }$ & & & $\sqrt{ }$ & $\sqrt{ }$ & $\sqrt{ }$ \\
\hline & Nostocaceae & 3 & +++ & & $\sqrt{ }$ & $\sqrt{ }$ & & $\sqrt{ }$ & $\sqrt{ }$ & $\sqrt{ }$ & $\sqrt{ }$ & & $\sqrt{ }$ \\
\hline & Chlamydomonadaceae & 1 & + & & & $\sqrt{ }$ & & & & & & & $\sqrt{ }$ \\
\hline & Volvocaceae & 2 & ++ & $\sqrt{ }$ & $\sqrt{ }$ & & & & & & $\sqrt{ }$ & $\sqrt{ }$ & \\
\hline & Oocystaceae & 1 & + & & & & $\sqrt{ }$ & & & & & & $\sqrt{ }$ \\
\hline \multirow[t]{4}{*}{ Chlorophyceae } & Scenedesmaceae & 2 & ++ & & $\sqrt{ }$ & & $\sqrt{ }$ & $\sqrt{ }$ & & $\sqrt{ }$ & & & \\
\hline & Chlorellaceae & 2 & ++ & $\sqrt{ }$ & $\sqrt{ }$ & & & & & & $\sqrt{ }$ & $\sqrt{ }$ & $\sqrt{ }$ \\
\hline & Coelastraceae & 1 & + & & & & & $\sqrt{ }$ & & & & & \\
\hline & Eutraeptiaceae & 1 & + & $\sqrt{ }$ & & $\sqrt{ }$ & & & & & & $\sqrt{ }$ & \\
\hline \multirow[t]{4}{*}{ Euglenophyceae } & Euglenaceae & 13 & ++ & & $\sqrt{ }$ & & & & & & $\sqrt{ }$ & $\sqrt{ }$ & $\sqrt{ }$ \\
\hline & Melosiraceae & 3 & ++ & $\sqrt{ }$ & & $\sqrt{ }$ & & $\sqrt{ }$ & & & $\sqrt{ }$ & $\sqrt{ }$ & \\
\hline & Coscinodiscaceae & 1 & ++ & & & $\sqrt{ }$ & & & & & & $\sqrt{ }$ & $\sqrt{ }$ \\
\hline & Fragilariaceae & 8 & +++ & & $\sqrt{ }$ & $\sqrt{ }$ & $\sqrt{ }$ & $\sqrt{ }$ & $\sqrt{ }$ & & $\sqrt{ }$ & & $\sqrt{ }$ \\
\hline \multirow[t]{5}{*}{ Bacillariophyceae } & Eunotiaceae & 1 & ++ & & & $\sqrt{ }$ & & & & & & $\sqrt{ }$ & $\sqrt{ }$ \\
\hline & Naviculaceae & 9 & +++ & $\sqrt{ }$ & $\sqrt{ }$ & & & & $\sqrt{ }$ & $\sqrt{ }$ & $\sqrt{ }$ & $\sqrt{ }$ & $\sqrt{ }$ \\
\hline & Cymbellaceae & 2 & +++ & $\sqrt{ }$ & & & $\sqrt{ }$ & $\sqrt{ }$ & & & $\sqrt{ }$ & & $\sqrt{ }$ \\
\hline & Bacillariaceae & 3 & ++ & & $\sqrt{ }$ & & & $\sqrt{ }$ & & & $\sqrt{ }$ & $\sqrt{ }$ & $\sqrt{ }$ \\
\hline & Surirellaceae & 1 & + & & & $\sqrt{ }$ & & & & & $\sqrt{ }$ & & \\
\hline
\end{tabular}

Here,$+=$ few; $++=$ common and $+++=$ very common

Total 62 species were identified, from the collected water samples from study area. Among them members of Bacillariophyceae were found to be dominant (Fig. 2). Total 28 species were found in class of Bacillariophyceae, where Fragilariaceae, Naviculaceae and Cymbellaceae were abundant than others. 14 species of Euglenophyceae, 11 Cyanophyceae and 9 Chlorophyceae species were also found. More or less similar observations were made by Begum and Khanam [15] in case of pharmaceuticals effluent. The taxa recorded in the present study along with their dimension and abundance in different sampling points is given in Table 2 in which the abundance of the three species family is; Euglenaceae, Fragilariaceae and Naviculaceae were evident. These species seem to be resistant to polluted environment. Begum and her group [15,37] also observed more or less similar abundance of these species by receiving effluents from the textile and pharmaceuticals industries. 


\subsection{Pollution effects on phytoplankton}

Generally, phytoplankton or algae are sensitive to pollutants. Growth and photosynthesis are closely related, each being a function of the utilization of light and nutrients. Dugdale [38] described the growth of an algal population as being proportional to the effect of light on photosynthesis, the concentration of nutrients, and the maximum specific growth rate. Industrial pollutants block the light for photosynthetic mechanism and inhibit growth. Pollutants can, therefore, affect photosynthesis and other aspects of energy utilization and incorporation and, thus cause changes in population growth rates. Pollutants may also affect the species composition of the phytoplankton community.

With a few exceptions, among all the groups of phytoplankton recorded, Cyanophyceae and Euglenophyceae showed dominance in all the collected samples (Table 2). Similar observation was also made earlier in textile industrial effluents [37] and in pharmaceuticals industry [15].

\section{in Bacillariophyceae iㅏ Euglenophyceae in Chlorophyceae iㅣ Cyanophyceae}


9

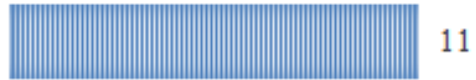

Fig. 2. Phytoplankton diversity and abundance in study area.

On the contrary lowest representation by the members of Chlorophyceae indicates that this group is more sensitive to the pollutants discharged by the industry. Similar observation was made by Begum and Khanam [15] for pharmaceuticals effluent discharge area. The members of Bacillariophyceae appear to be best adapted in the polluted habitat as indicated by 28 species out of 62 . The present investigation revealed that the effluents discharged from industries are very harmful for the phytoplankton as well as aquatic ecosystem, and the species is reduced as 78 species were found previously by Begum and Khanam [15] and 308 by Begum and Hossain [11] in Shitalakhya River.

\section{Conclusion}

From the present study, it has been found that, pollutant water is very harmful for phytoplankton diversity as well as the aquatic ecosystem. Bacillariophyceae were found to 
be dominant in study area as appear to be best adapted in the polluted habitat and Chlorophyceae were more sensitive to the pollutants. The abundance of phytoplankton was found comparatively less polluted area and lowest near the pollution source. The ecosystem of Shitalakhya River is now fallen in threatened condition due to productivity imbalance by effluent discharge.

\section{Acknowledgement}

Authors are grateful to the faculty and stuff of Department of Environmental Sciences, Jahangirnagar University for their support to conduct this work.

\section{References}

1. E. C. Pielou and Freshwater (University of Chicago Press, 1998) pp. 286.

2. BCAS (Bangladesh Center for Advance Studies) Pollution Study Management of Aquatic Ecosystem through Community Husbandry (MACH) (Dhaka, Bangladesh, 2000).

3. I. C. Onyema, Eur. J. Sci. Res. 43, 61 (2010)

4. K. V. Ajayan and N. Parameswara, India. Int. Res. J. Env. Sci. 3(4), 34 (2014).

5. R. Patrick, ASTM.STP, 528, 76 (1973).

6. B. Sarwade and N. A. Kamble, J. Eco. Nature Env. 6(4), 174 (2014).

7. R. P. King and G. E. Jonathan, Aquatic Environmental Perturbations and Monitoring (African Experience, Texas, USA (2003) pp. 166.

8. J. F. N. Abowei and F. D. Sikoki, Water pollution management and control (Doubletrust Publication Company, Nigeria, 2005) pp. 236.

9. M. Khondker, A. K. M. N. Islam, Z. N. T. Begum, and S. Haque, Bang. J. Bot. 19(1), 51 (1990).

10. A. K. M. N. Islam, M. Khondker, and S. Haque, Bang. J. Bot. 20(1), 7 (1991).

11. Z. N. T. Begum and M. Z. Hossain, Dhaka Univ. J. Bio. Sci. 2(1), 93 (1993).

12. M. A. I. Khan, A. M. Hossain, M. E. Huda, M. S. Islam, and S. F. Elahi, Bang. J. Sci. Ind. Res. 42(4), 377 (2007).

13. K. Kaewsri, S. Traichaiyaporn, Thailand. J. Agri. Technol. 8(2), 537 (2012).

14. E. P. Odum and G. W. Barrett, Fundamentals of ecology, $5^{\text {th }}$ edition (Thomson Brooks, Australia, 2008).

15. Z. N. T. Begum and D. Khanam, Bang. J. Bot. 38 (1), 77 (2009).

16. APHA (American Public Health Association), Standard Methods for Examination of Water and Wastewater, $21^{\text {st }}$ edition (Washington DC, 2005) pp. 15.

17. M. Khondker, A. K. M. N. Islam and R. Islam, Dhaka Univ. Stud. Part E 3(1), 15 (1988).

18. D. Johansen, Plant Micro Technique (McGraw Hill Book Company Inc. N.Y., 1940) pp. 523.

19. H. C. Bold and M. J. Wynne, Introduction to the Algae (Prentice-Hall, New Jersey, 1985) pp. 1-706.

20. V. Kumar, S. Arya, A. Dhaka, and C. Minakshi, India. Int. Multi. Res. J. 1(5), 14 (2011).

21. ECR (Environmental Conservation Rules), Government of the People's Republic of Bangladesh, Ministry of Environment and Forest (Department of Environment, Dhaka, Bangladesh, 1997) pp. 212-214.

22. M. Rajasegar, J. Env. Bio. 24, 95 (2003).

23. ADB (Asian Development Bank), Training Manual for Environmental Monitoring (Eng. Sci. Incorporation, USA, 1994) pp. 2-26.

24. M. R. Mahananda, India. Int. J. Res. Rev. Appl. Sci. 2(3), 284 (2010).

25. R. K. Trivedi, P. K. Goel, Chemical and Biological Methods for Water Pollution Studies (Environmental Publications, Karad, 1984).

26. A. Mishra, A. Mukherjee, and B. D. Tripathi, Int. J. Env. Res. 3(3), 395 (2009). 
27. S. S. Dara, A Textbook of Environmental Chemistry and Pollution Control. $7^{\text {th }}$ edition (S. Chand and Company Ltd., RamNagar, New Delhi, India, 2007) pp. 44-75.

28. R. J. Chhatwal, Environment Sciences: A Systematic Approach. 2nd edition (UDH Publishers and Distributors (P) Ltd., 2011) pp. 104-105.

29. M. J. B. Alam, Z. Muyen, M. R. Islam, S. Islam, and M. Mamun, Int. J. Env. Sci. Technol. 4(1), 159 (2007). http://dx.doi.org/10.1007/BF03325974

30. A. K. De, Environmental Chemistry. $5^{\text {th }}$ edition (New Age International (P) Ltd., Daryagang, New Delhi, India, 2005) pp. 187.

31. J. W. Meade, Aquaculture Management (CBS Publishers and Distributors, New Delhi, India, 1998) pp. 9.

32. A. G. Chowdhury and A. Chowdhury, An Assessment of Water Resources and Flood Management of Dhaka City, Water Resources Management and Development in Dhaka City, Geothe-institute (Dhaka, Bangladesh, 2004) pp. 40-45.

33. EQS (Environmental Quality Standard), Government of the People's Republic of Bangladesh, Ministry of Environment and Forest, Department of Environment, (Gazette, registered No. DA-1, Dhaka, Bangladesh, 1997).

34. H. Pathak and S. N. Limaye, Interdependency between Physicochemical Water Pollution Indicators: A Case Study of River Babus, Sagar, M.P., India (Analele UniversităŃii din Oradea - Seria Geografie (June) Article no. 211103-515, 2011) pp. 23.

35. D. Mamais, D. Jenkins, and P. Prrr, Water Res. 27(1), 195 (1993). http://dx.doi.org/10.1016/0043-1354(93)90211-Y

36. S. M. D. Islam and G. Azam, J. Bio. Env. Sci. 7(3), 120 (2015).

37. Z. N. T. Begum, Bang. J. Plant Taxon 15(2), 129 (2008). http://dx.doi.org/10.3329/bjpt.v15i2.1742

38. R. C. Dugdale, Biological modelling I. In Modelling of Marine Systems, $1^{\text {st }}$ edition (Elsevier, New York, 1975) pp. 187-205. http://dx.doi.org/10.1016/S0422-9894(08)71000-6 